\title{
Soil physical quality in response to intensification of grain production systems
}

\author{
Paula K. Mota ${ }^{1}$, Bruno M. Silva ${ }^{2}$, Emerson Borghi ${ }^{3}$, João H. M. Viana ${ }^{3}$, Álvaro V. de Resende ${ }^{3}$ \& \\ Maíse S. de Moura ${ }^{1}$ \\ ${ }^{1}$ Universidade Federal de São João del-Rei/Programa de Pós-Graduação em Ciências Agrárias. Sete Lagoas, MG, Brasil. E-mail: pk_mota@yahoo.com.br \\ (Corresponding author) - ORCID: 0000-0002-6796-8740; maisedemoura@hotmail.com - ORCID: 0000-0002-1319-0347 \\ ${ }^{2}$ Universidade Federal de Lavras/Departamento de Ciência do Solo. Lavras, MG, Brasil. E-mail: montoani@gmail.com - ORCID: 0000-0002-8240-8987 \\ ${ }^{3}$ Empresa Brasileira de Pesquisa Agropecuária/Embrapa Milho e Sorgo. Sete Lagoas, MG, Brasil. E-mail: emerson.borghi@embrapa.br - ORCID: 0000-0003- \\ 3094-622X; joao.herbert@embrapa.br - ORCID: 0000-0002-5872-4816; alvaro.resende@embrapa.br - ORCID: 0000-0001-5438-4052
}

\begin{abstract}
The Brazilian Cerrado stands out in relation to grain production, however, in this region the occurrence of summer and irregular rainfall, drastically harm the non-irrigated production. Conservationist managements favor the soil physical quality and, consequently, the efficiency of soil water consumption. The objective of this study was to evaluate the soil physical quality, as a function of the conservation managements adopted, by using physical soil quality indicators, and to verify its relation with the soil organic carbon stocks and the grain yield in the Cerrado of Minas Gerais state, Brazil. For that, six treatments were evaluated: soybean (1) and maize (2) monocultures crop systems at medium level of investment in soil fertilization, soybean-maize crop succession at medium (3) and high (6) level of investment in soil fertilization, and crop succession of soybean-maize and intercropped with Urochloa ruziziensis at medium (4) and high (5) level of investment in soil fertilization, during the initial stage of no-tillage system. The treatments 3, 4, 5 and 6 showed improvement in the soil physical quality in relation to the monoculture. Pore distribution and soil organic carbon content were the main responsible for discriminating the intensified crop systems. Attributes related to water availability were important for plant growth in the 0-0.05 m layer, while for the 0.15-0.20 m layer, the highest soil aeration stood out. Productivity did not correlate with the evaluated attributes.
\end{abstract}

Key words: Urochloa ruziziensis, soil management, soil water properties, crop rotations, principal component analysis

\section{Qualidade física do solo em resposta à intensificação de sistemas de produção de grãos}

RESUMO: O Cerrado brasileiro se destaca com relação à produção de grãos, no entanto, nesta região a ocorrência de veranicos e pluviosidade irregular prejudica drasticamente a produção não irrigada. Manejos conservacionistas favorecem a qualidade física do solo e, por consequência, a eficiência do consumo de água do solo. Desta forma, o objetivo deste estudo foi avaliar a qualidade física do solo, em função dos manejos conservacionistas adotados, por meio do uso de indicadores de qualidade física do solo, e verificar sua relação com o estoque de carbono no solo e a produtividade de grãos no Cerrado mineiro. Para tal, foram avaliados seis tratamentos: sistemas de monocultura de soja (1) e de milho (2) em nível médio de investimento em adubação, sucessão soja-milho em nível médio (3) e alto (6) de investimento em adubação, e sucessão sojamilho consorciado com braquiária (Urochloa ruziziensis) em nível médio (4) e alto (5) de investimento em adubação, na fase de implantação do plantio direto. Os tratamentos 3, 4, 5 e 6 apresentaram melhoria na qualidade física do solo em relação ao monocultivo. Indicadores da distribuição dos poros e carbono orgânico foram os principais responsáveis por discriminarem os sistemas intensificados. Atributos relacionados à disponibilidade de água foram importantes para o crescimento vegetal na camada de $0-0,05 \mathrm{~m}$, enquanto que para a camada de $0,15-0,20 \mathrm{~m}$ destacou-se a maior aeração do solo. A produtividade não se correlacionou com os atributos avaliados.

Palavras-chave: Urochloa ruziziensis, manejo do solo, propriedades hídricas do solo, sucessão de culturas, análise de componentes principais 


\section{INTRODUCTION}

The Cerrado biome in Brazil presents climate restrictions for agricultural productions, with occurrence of dry spells and irregular rainfall distribution, hindering rainfed crop yields and affecting water reserves for irrigated crops. Thus, conservationist managements that make possible to increase the soil capacity to provide water to plants and improve root development to deeper depths can decrease the severity of the harmful effects of dry spells on these crops (Borghi et al., 2013; Silva et al., 2015).

However, conservationist practices such as the no-tillage system (NTS) present limitations in these regions due to difficulty in forming the soil plant cover. Several studies have been conducted to improve the efficiency of this system, showing the benefits of using perennial grass species intercropped with grain crops (Borghi et al., 2013; Crusciol et al., 2015). Intercrops present positive results that improve the soil physical and biological qualities (Calonego et al., 2017; Pariz et al., 2017). They provide higher availability of nutrients in the soil, resulting in improvements in fertility and higher yields for succeeding crops (Borghi et al., 2013; Crusciol et al., 2015; Balbinot et al., 2017; Pariz et al., 2017).

Therefore, information on effects of management practices on the soil physical quality (SPQ) when establishing the NTS is essential under these climate conditions. Thus, the objective of the present work was to evaluate the SPQ and water availability in different crop systems at the initial stage of the NTS implementation in a region of the Cerrado biome in the state of Minas Gerais, Brazil. The hypothesis was that the tested intensive crop systems at the initial stage of NTS implementation improve the SPQ.

\section{Material ANd Methods}

The experiment was conducted in a grain production area of the Brazilian Agricultural Research Corporation (Embrapa - Maize and Sorghum), in the municipality of Sete Lagoas, Minas Gerais, Brazil $\left(19^{\circ} 45^{\prime} \mathrm{S}, 44^{\circ} 17^{\prime} \mathrm{W}\right.$, and mean altitude of $735.3 \mathrm{~m}$ ). The climate of the region is Cwa, subtropical wet, according to the Köppen-Geiger classification (Kottek et al., 2006), with mean annual temperature of $22.1^{\circ} \mathrm{C}$ and mean annual rainfall of $1,382.7 \mathrm{~mm}$, concentrated from October to April. The experiment area had 4.4 ha; the soil was classified as an Oxisol, presenting 190, 120, and $690 \mathrm{~g} \mathrm{~kg}^{-1}$ of sand, silt, and clay, respectively, and mineralogy with predominance of kaolinite. The area was used for maize and soybean crops under conventional tillage system over the 20 previous years to the implementation of the experiment.

In August 2014, a subsoiling up to the depth of $0.35 \mathrm{~m}$ was carried out in the whole area to eliminate possible compacted layers, and lime and fertilizers were incorporated to the soil to favor the establishment of no-tillage system (NTS). The initial operations were focused on reaching higher depths than those used for the soil preparation practiced in the region $(0.20 \mathrm{~m})$. Limestone was applied in September 2014, using $4 \mathrm{Mg} \mathrm{ha}^{-1}$ divided into two applications: the first was incorporated to the soil with a moldboard plow, and the second with a harrow. In October 2014, gypsum was applied to the soil surface using $3 \mathrm{Mg} \mathrm{ha}^{-1}$, and fertilizers containing 3.9\% sulfur, $1.8 \%$ boron, $0.85 \%$ copper, $2 \%$ manganese, and $9 \%$ zinc $\left(93 \mathrm{~kg} \mathrm{ha}^{-1}\right)$ and potassium chloride (306 $\left.\mathrm{kg} \mathrm{ha}^{-1}\right)$ and simple superphosphate $\left(1.100 \mathrm{~kg} \mathrm{ha}^{-1}\right)$ were applied and incorporated to the soil with a harrow leveler. All operations to build the soil fertility and soil preparation occurred without rainfall, and the quantities of inputs were calculated to accomplish the correct management of soil fertility, following the recommendations described in the manual of recommendations for the region (Souza \& Lobato, 2004; Resende et al., 2016).

The treatments were distributed into six strips, with the different crop systems, which had different levels of investment in soil fertilization; each treatment had an area of 0.5 ha. The crop systems consisted of monocultures, successions, and treatments combining crop succession and intercrop in the same strip (Table 1). The levels of investment in soil fertilization were based on the demands for a high maize and soybean grain yields (Resende et al., 2016). The nutritional requirements were completely (high level of investment) or partially (medium level of investment) met (Table 1). The predominant climate conditions in the region of Sete Lagoas, MG, Brazil, do not enable the growth of winter crops. Thus, the treatments were defined based on annual successions of soybean and maize and the introduction of a grass species (Urochloa ruziziensis) for intercrops to increase biomass production, which favors the following crops, mainly regarding the rainfall water use, and decreases yield losses caused by occurrence of dry spells. The crops were sown, according to the treatments used, after the beginning of the rainy season, in December 2014.

Table 1. Characterization of the treatments regarding crop systems and levels of investment in soil fertilization, considering the quantities of nitrogen $(\mathrm{N})$, phosphorus, $\left(\mathrm{P}_{2} \mathrm{O}_{5}\right)$ and potassium $\left(\mathrm{K}_{2} \mathrm{O}\right)$ applied to the crops grown in each crop season

\begin{tabular}{|c|c|c|c|c|c|c|c|}
\hline \multirow{2}{*}{ Treatments } & \multirow{2}{*}{$\begin{array}{l}\text { Levels of investment in } \\
\text { soil fertilization }\end{array}$} & \multirow{2}{*}{$\begin{array}{l}\text { Crop } \\
\text { season }\end{array}$} & \multirow{2}{*}{ Summer } & \multirow{2}{*}{ Autumn-Spring } & \multicolumn{3}{|c|}{ Fertilizer (kg ha-1) } \\
\hline & & & & & $\mathbf{N}$ & $\mathrm{P}_{2} \mathrm{O}_{5}$ & $\mathrm{~K}_{2} \mathrm{O}$ \\
\hline \multirow[b]{2}{*}{1} & \multirow{2}{*}{ Medium } & $2014 / 15$ & Soybean & Fallow & 8.2 & 82 & 82 \\
\hline & & $2015 / 16$ & Soybean & Fallow & 7 & 70 & 70 \\
\hline \multirow[b]{2}{*}{2} & \multirow{2}{*}{ Medium } & $2014 / 15$ & Maize & Fallow & 33.2 & 116.2 & 66.4 \\
\hline & & $2015 / 16$ & Maize & Fallow & 24 & 84 & 48 \\
\hline \multirow{2}{*}{3} & \multirow{2}{*}{ Medium } & $2014 / 15$ & Maize & Fallow & 33.2 & 116.4 & 66.4 \\
\hline & & $2015 / 16$ & Soybean & Fallow & 7 & 70 & 70 \\
\hline \multirow{2}{*}{4} & \multirow{2}{*}{ Medium } & $2014 / 15$ & Maize + U. ruziziensis & U. ruziziensis & 33.2 & 116.2 & 66.4 \\
\hline & & $2015 / 16$ & Soybean + U. ruziziensis & U. ruziziensis & 7 & 70 & 70 \\
\hline \multirow{2}{*}{5} & \multirow{2}{*}{ High } & $2014 / 15$ & Soybean + U. ruziziensis & U. ruziziensis & 9.6 & 95.8 & 95.8 \\
\hline & & $2015 / 16$ & Maize $+U$. ruziziensis & U. ruziziensis & 36 & 126 & 72 \\
\hline \multirow{2}{*}{6} & \multirow{2}{*}{ High } & $2014 / 15$ & Soybean & Fallow & 9.6 & 95.8 & 95.8 \\
\hline & & $2015 / 16$ & Maize & Fallow & 36 & 126 & 72 \\
\hline
\end{tabular}


Three georeferenced points were randomly chosen for each treatment and undisturbed soil samples were collected in March 2016, when the soil was under use for crops sown in November 2015 (2015-2016 crop season). The sampling was defined after tests with a penetrometer, thus selecting layers that had higher resistance to penetration, which indicate higher limitation for root growth; these layers were 0-0.05 and 0.15-0.20 m. Seven cylinders of soil of each layer were collected in each point, resulting in 42 cylinders per treatment and a total of 252 cylinders.

The samples were prepared, saturated, and separated into seven groups of 36 samples. Each group of samples was subjected to a different matric potential $(\Psi)$ to assess the water retention curve. The $\Psi$ used were $-4,-6$, and $-10 \mathrm{kPa}$ in an automatic tension table (EcoTech), and $-33,-100,-500$, and $-1500 \mathrm{kPa}$ in a Richards extractor (Donagemma et al., 2011). The samples were weighed after reaching water equilibrium and taken to an oven to obtain a constant weight to determine the soil volumetric water content $(\theta)$ in each $\Psi$. The $\theta$ and $\Psi$ data were fitted to the model proposed by Genuchten (1980).

The model of the water retention curve was used to calculate SPQ. The total porosity was used as equivalent to the saturation moisture $(\theta s)$. Microporosity was determined by the $\theta$ in equilibrium with a $\Psi$ of $-6 \mathrm{kPa}$, and macroporosity was determined by the difference between total porosity and microporosity. The plant-available water capacity (PAWC) was determined by the difference between the field capacity estimated by the water content withheld at $-6 \mathrm{kPa}$, as indicated for clayey oxidic Oxisols of the Cerrado biome by Silva et al. (2014), and the permanent wilting point at $-1.500 \mathrm{kPa}$. The PAWC was used to calculate the readily available water (RAW), considering the depletion fraction for the maize crop ( $\mathrm{p}$ factor $=$ 0.54 ) and soybean crop ( $\mathrm{p}$ factor $=0.59$ ), according to Allen et al. (1998). The S Index was calculated to indicate the heterogeneity of the distribution of pores by size, as proposed by Dexter (2004). The relative water capacity (RWC) was calculated by the ratio between field capacity and $\theta$ s and indicated the balance between soil capacity to provide water and air (Reynolds et al., 2008).

The soil organic carbon stocks (SOCS) in each soil layer were calculated by the expression: $\operatorname{SOCS}\left(\mathrm{Mg} \mathrm{ha}^{-1}\right)=\mathrm{OC} \times \mathrm{BD} \times \mathrm{T} / 10$, where OC is the soil organic carbon content $\left(\mathrm{g} \mathrm{kg}^{-1}\right), \mathrm{BD}$ is the bulk density in the sampled layer $\left(\mathrm{kg} \mathrm{dm}^{-3}\right)$, and $\mathrm{T}$ is the soil layer thickness $(\mathrm{cm})$. The $\mathrm{OC}$ and BD were determined by procedures described by Donagemma et al. (2011).

The crop yield of each treatment was calculated by collecting all grains in 3 meters of 3 rows in each georeferenced point and estimating them in $\mathrm{kg} \mathrm{ha}^{-1}$. The yield proportions in relation to the maximum estimated yield for each crop $\left(10,399.80 \mathrm{~kg} \mathrm{ha}^{-1}\right.$ for maize and $3,103.83 \mathrm{~kg} \mathrm{ha}^{-1}$ for soybean) were used to calculate the relative yield (RY), according to Borghi et al. (2013).

The sampling had pseudo-replications due to restrictions for randomization inherent to experiments conducted in large strips (Cecagno et al., 2016); thus, the data were subjected to multivariate statistical analysis, with the two soil layers evaluated separately by principal component analysis (PCA). The data variance and covariance were presented in the PCA by linear combinations (principal components), which enabled the simultaneous evaluation of the SPQ, SOCS, and $\mathrm{RY}$ indicators. A group analysis was carried out to differentiate the evaluated managements, using dendrograms formed by the dissimilarity levels measured by the mean Euclidean distance, through the Ward's method. Pearson correlation analyses were used for the evaluated variables at $\mathrm{p} \leq 0.05$. The data normality was previously evaluated by the Shapiro-Wilk test. All analyses were carried out using the R program (R Core Team, 2017) with the ggbiplot package for the visualization of the PCA, the vegan package for the building of the dendrograms, and the agricolae package for the correlation analyses.

\section{Results AND Discussion}

The results of the SPQ indicators were compared to those considered adequate, without restrictions for plant growth, according to data available in the literature (Table 2). Macroporosities between 0.10 and 0.15 are used as the minimum adequate values for medium to clayey texture soils (Andrade \& Stone, 2009). The medium macroporosity were above $0.10 \mathrm{~m}^{3} \mathrm{~m}^{-3}$ in all treatments in both soil layers evaluated, indicating absence of aeration limitations and efficiency in the soil preparation for implementation of NTS.

The soil densities (BD) found were lower than the maximum limit $\left(1.34 \mathrm{~kg} \mathrm{dm}^{-3}\right)$ in all treatments due to the soil preparation for the implementation of the experiment; according to Andrade \& Stone (2009), this BD limit is critical for the validation of the S Index in soils in the Cerrado biome. Reichert et al. (2009) reported decreases in root elongation for $\mathrm{BD}>1.21$ (750 $\mathrm{g} \mathrm{kg}^{-1}$ of clay) or $>1.36 \mathrm{~g} \mathrm{~cm}^{-3}\left(650 \mathrm{~g} \mathrm{~kg}^{-1}\right.$ of clay) for soybean crops under NTS. Therefore, the BD is not a limiting factor for plant growth and productivity. Oxidic Oxisols without agricultural use present, in general, $\mathrm{BD}<1 \mathrm{~g} \mathrm{~cm}^{-3}$ and Mac $>0.10 \mathrm{~m}^{3} \mathrm{~m}^{-3}$, resulting in granular structures, which cause a fast drainage (Silva et al., 2014) and, thus, seldom present soil oxygen diffusion as a limitation for plant development, even under intensive soil management (Silva et al., 2015).

The medium PAWC was lower than the lower optimal limit of $0.15 \mathrm{~m}^{3} \mathrm{~m}^{-3}$ in the treatments 1,2 , and 3 in both soil layers evaluated, and in the treatment 6 in the $0.15-0.20 \mathrm{~m}$ layer, indicating water limitation for root growth (Table 2). The treatments 1 and 2 showed minimum PAWC lower than $0.10 \mathrm{~m}^{-3}$, indicating very low capacity of supplying water to plants (Reynolds et al., 2008). The medium PAWC in the optimal range was found for the production system with succession and intercrop with high investment (Treatment 5) in both layers (Table 2). Despite the reference values for PAWC are based on soils of temperate climate, Silva et al. (2014) found similar values for Oxisols in the Cerrado biome (tropical).

Only the maize monoculture (Treatment 2 ) had medium $S$ Index (Table 2) with trend to structural degradation $(<0.045)$, with the minimum value indicating physically degraded soils (Andrade \& Stone, 2009). The high medium S Indexes (>0.045) found in the other treatments indicate good structural quality (Andrade \& Stone, 2009); however, they also indicate low presence of intermediate-size pores, which can affect negatively the water availability to plants. 
Table 2. Maximum, minimum, and medium values of soil quality indicators found for different agricultural soil management systems in the 0-0.05 and 0.15-0.20 m soil layers and relative crop yield, and optimal ranges described in the literature for these indicators

\begin{tabular}{|c|c|c|c|c|c|c|c|c|c|c|c|c|c|}
\hline Treatments & Value & BD & Mic & Mac & RWC & PAWC & RAW & SM & $\bar{n}$ & $S$ & $\mathrm{OC}$ & SOCS & RY \\
\hline \multirow{8}{*}{1} & \multicolumn{13}{|c|}{$0-0.05 \mathrm{~m}$} \\
\hline & Maximum & 1.230 & 0.444 & 0.132 & 0.849 & 0.130 & 0.076 & 0.553 & 1.431 & 0.055 & 2.18 & 12.54 & 100.0 \\
\hline & Minimum & 1.088 & 0.414 & 0.077 & 0.758 & 0.127 & 0.075 & 0.519 & 1.289 & 0.041 & 2.04 & 11.86 & 91.3 \\
\hline & Medium & 1.173 & 0.430 & 0.105 & 0.804 & 0.129 & 0.076 & 0.533 & 1.358 & 0.048 & 2.09 & 12.23 & 96.2 \\
\hline & \multicolumn{13}{|c|}{$0.15-0.20 \mathrm{~m}$} \\
\hline & Maximum & 1.158 & 0.407 & 0.125 & 0.781 & 0.127 & 0.075 & 0.549 & 1.539 & 0.059 & 2.09 & 12.08 & 100.0 \\
\hline & Minimum & 1.067 & 0.406 & 0.114 & 0.764 & 0.094 & 0.055 & 0.520 & 1.272 & 0.039 & 1.75 & 9.41 & 91.3 \\
\hline & Medium & 1.113 & 0.407 & 0.121 & 0.771 & 0.114 & 0.067 & 0.537 & 1.386 & 0.048 & 1.87 & 10.40 & 96.2 \\
\hline \multirow{8}{*}{2} & \multicolumn{13}{|c|}{$0-0.05 \mathrm{~m}$} \\
\hline & Maximum & 1.123 & 0.413 & 0.180 & 0.775 & 0.171 & 0.092 & 0.608 & 1.226 & 0.050 & 2.25 & 11.68 & 80.3 \\
\hline & Minimum & 0.994 & 0.401 & 0.119 & 0.689 & 0.069 & 0.037 & 0.545 & 1.077 & 0.015 & 2.08 & 11.17 & 93.6 \\
\hline & Medium & 1.071 & 0.408 & 0.155 & 0.726 & 0.128 & 0.069 & 0.580 & 1.144 & 0.037 & 2.14 & 11.42 & 82.5 \\
\hline & \multicolumn{13}{|c|}{$0.15-0.20 \mathrm{~m}$} \\
\hline & Maximum & 1.085 & 0.409 & 0.161 & 0.785 & 0.121 & 0.066 & 0.562 & 1.573 & 0.068 & 2.45 & 13.15 & 80.3 \\
\hline & Minimum & 1.064 & 0.389 & 0.112 & 0.716 & 0.111 & 0.060 & 0.544 & 1.221 & 0.042 & 1.99 & 10.59 & 93.6 \\
\hline & Medium & 1.075 & 0.401 & 0.135 & 0.749 & 0.117 & 0.063 & 0.552 & 1.363 & 0.052 & 2.28 & 12.27 & 82.5 \\
\hline \multirow{8}{*}{3} & \multicolumn{13}{|c|}{$0-0.05 \mathrm{~m}$} \\
\hline & Maximum & 1.051 & 0.392 & 0.213 & 0.688 & 0.142 & 0.084 & 0.602 & 1.882 & 0.115 & 2.79 & 12.84 & 97.3 \\
\hline & Minimum & 0.922 & 0.374 & 0.177 & 0.637 & 0.118 & 0.070 & 0.591 & 1.199 & 0.052 & 2.39 & 12.53 & 100.0 \\
\hline & Medium & 0.986 & 0.385 & 0.198 & 0.660 & 0.126 & 0.074 & 0.596 & 1.490 & 0.079 & 2.59 & 12.69 & 100.0 \\
\hline & \multicolumn{13}{|c|}{$0.15-0.20 \mathrm{~m}$} \\
\hline & Maximum & 1.011 & 0.409 & 0.242 & 0.687 & 0.134 & 0.079 & 0.589 & 1.977 & 0.120 & 2.50 & 12.42 & 97.3 \\
\hline & Minimum & 0.908 & 0.357 & 0.173 & 0.597 & 0.128 & 0.075 & 0.578 & 1.567 & 0.080 & 2.28 & 10.34 & 100.0 \\
\hline & Medium & 0.964 & 0.381 & 0.200 & 0.657 & 0.130 & 0.077 & 0.582 & 1.722 & 0.094 & 2.41 & 11.64 & 100.0 \\
\hline \multirow{8}{*}{4} & \multicolumn{13}{|c|}{$0-0.05 \mathrm{~m}$} \\
\hline & Maximum & 1.098 & 0.437 & 0.161 & 0.784 & 0.160 & 0.094 & 0.585 & 1.330 & 0.063 & 2.83 & 15.53 & 91.8 \\
\hline & Minimum & 1.036 & 0.410 & 0.120 & 0.721 & 0.140 & 0.083 & 0.561 & 1.188 & 0.045 & 2.64 & 13.69 & 99.5 \\
\hline & Medium & 1.066 & 0.422 & 0.147 & 0.743 & 0.150 & 0.089 & 0.571 & 1.278 & 0.055 & 2.72 & 14.49 & 97.7 \\
\hline & \multicolumn{13}{|c|}{$0.15-0.20 \mathrm{~m}$} \\
\hline & Maximum & 1.167 & 0.457 & 0.149 & 0.843 & 0.171 & 0.101 & 0.565 & 1.462 & 0.066 & 2.49 & 14.46 & 91.8 \\
\hline & Minimum & 1.068 & 0.392 & 0.085 & 0.725 & 0.126 & 0.074 & 0.545 & 1.144 & 0.040 & 2.45 & 13.09 & 99.5 \\
\hline & Medium & 1.108 & 0.420 & 0.123 & 0.774 & 0.145 & 0.086 & 0.553 & 1.291 & 0.051 & 2.47 & 13.70 & 97.7 \\
\hline \multirow{8}{*}{5} & \multicolumn{13}{|c|}{$0-0.05 \mathrm{~m}$} \\
\hline & Maximum & 1.058 & 0.419 & 0.224 & 0.738 & 0.178 & 0.096 & 0.612 & 1.819 & 0.120 & 2.68 & 14.15 & 100.0 \\
\hline & Minimum & 0.969 & 0.387 & 0.148 & 0.636 & 0.135 & 0.073 & 0.560 & 1.245 & 0.067 & 2.59 & 12.55 & 99.7 \\
\hline & Medium & 1.000 & 0.399 & 0.190 & 0.679 & 0.163 & 0.088 & 0.592 & 1.494 & 0.085 & 2.62 & 13.11 & 100.0 \\
\hline & \multicolumn{13}{|c|}{$0.15-0.20 \mathrm{~m}$} \\
\hline & Maximum & 1.063 & 0.433 & 0.206 & 0.739 & 0.199 & 0.107 & 0.627 & 1.773 & 0.116 & 2.63 & 12.78 & 100.0 \\
\hline & Minimum & 0.971 & 0.378 & 0.148 & 0.647 & 0.151 & 0.082 & 0.598 & 1.187 & 0.056 & 2.34 & 12.41 & 99.7 \\
\hline & Medium & 1.027 & 0.410 & 0.180 & 0.696 & 0.176 & 0.095 & 0.612 & 1.431 & 0.083 & 2.46 & 12.63 & 100.0 \\
\hline \multirow{11}{*}{6} & & & & & & & $05 \mathrm{~m}$ & & & & & & \\
\hline & Maximum & 1.145 & 0.450 & 0.198 & 0.773 & 0.171 & 0.092 & 0.586 & 1.586 & 0.086 & 2.76 & 15.77 & 77.0 \\
\hline & Minimum & 0.979 & 0.386 & 0.132 & 0.662 & 0.145 & 0.078 & 0.568 & 1.386 & 0.065 & 2.07 & 10.15 & 100.0 \\
\hline & Medium & 1.056 & 0.416 & 0.162 & 0.720 & 0.155 & 0.084 & 0.575 & 1.483 & 0.075 & 2.42 & 12.84 & 82.9 \\
\hline & & & & & & & $0.20 \mathrm{~m}$ & & & & & & \\
\hline & Maximum & 1.151 & 0.432 & 0.170 & 0.774 & 0.143 & 0.077 & 0.589 & 1.705 & 0.084 & 2.55 & 14.68 & 77.0 \\
\hline & Minimum & 1.100 & 0.414 & 0.125 & 0.708 & 0.135 & 0.073 & 0.569 & 1.352 & 0.064 & 2.34 & 13.02 & 100.0 \\
\hline & Medium & 1.121 & 0.425 & 0.151 & 0.739 & 0.139 & 0.075 & 0.578 & 1.491 & 0.071 & 2.47 & 13.84 & 82.9 \\
\hline & & & & & & ues four & in the lit & ature & & & & & \\
\hline & Maximum & $1.34^{b}$ & - & $0.15^{b}$ & $0.7^{\mathrm{a}}$ & $0.20^{\mathrm{a}}$ & - & - & - & $0.045^{b}$ & $5^{a}$ & - & - \\
\hline & Minimum & $1.08^{b}$ & - & $0.10^{\mathrm{b}}$ & $0.6^{\mathrm{a}}$ & $0.15^{\mathrm{a}}$ & - & - & - & $0.025^{b}$ & $3^{a}$ & - & - \\
\hline
\end{tabular}

BD - Bulk density $\left(\mathrm{kg} \mathrm{dm}^{-3}\right)$; Mic - Soil microporosity $\left(\mathrm{m}^{3} \mathrm{~m}^{-3}\right) ; \mathrm{Mac}$ - Soil macroporosity $\left(\mathrm{m}^{3} \mathrm{~m}^{-3}\right)$; RWC - Relative water capacity; PAWC - Plant-available water capacity $\left(\mathrm{m}^{3} \mathrm{~m}^{-3}\right)$; RAW - Readily available water $\left(\mathrm{m}^{3} \mathrm{~m}^{-3}\right)$; SM - Saturation moisture $\left(\mathrm{m}^{3} \mathrm{~m}^{-3}\right) ; \mathrm{n}$ - Fit parameter of the soil water retention curve; S - S Index; OC - Soil organic carbon content $(\%)$; SOCS - Soil organic carbon stocks ( $\mathrm{Mg} \mathrm{ha}^{-1}$ ); RY (\%) - Relative yield of the 2015/2016 crop season; a - Reynolds et al. (2008); b - Andrade \& Stone (2009); The other indicators have no proposed limits; 1 - Soybean monoculture; 2 - Maize monoculture; 3 - Soybean-maize succession with medium investment; 4 - Soybean-maize + Urochloa ruziziensis succession with medium investment; 5 - Soybean-maize + Urochloa ruziziensis succession with high investment; 6 - Soybean-maize succession with high investment

RWC where within the indicated limits only for the treatments 3 and 5 (Table 2). The other treatments showed RCW higher than 0.7. According to Reynolds et al. (2008), this indicates a possible decrease in microbial activity due to insufficient soil air availability capacity; however, their proposed values are not consistent with the results found in the present study for soils of the Cerrado biome, which indicated no soil aeration limitation due to macroporosity. The RWC indicates which soil limitation (aeration or water) is the most serious for agricultural production, with optimal range proposed for crops of $0.6 \leq \mathrm{RWC} \leq 0.7$ (Reynolds et al., 2008). However, these limits were established for soils under temperate climate, thus requiring adaptations for tropical climate conditions. 
The OC values found in all treatments were below the lower limit of the optimal range of 3 to $5 \%$, which is related to the maximum production of field crops (Reynolds et al., 2008). OC is an important soil quality indicator and is related to SPQ, affecting the soil porosity and, consequently, the soil capacity to provide water and air to plants, the water infiltration, and the susceptibility to erosion (Reynolds et al., 2008). In addition, OC is a source of nutrients and is essential to generate the soil charges due to the advanced weathering stage of soils in the Cerrado biome.

The treatments 1 and 2 (soybean and maize monocultures) presented OC contents lower than the critical limit of $2.3 \%$ (Table 2), which result in losses in SPQ (Reynolds et al., 2008). However, the other treatments presented OC above the critical limit, indicating that these managements have contributed to maintain the soil quality. The adoption of management strategies, such as the crop successions present in the NTS, combined with intercrop with grass species in intensive crop systems provides a higher contribution of organic matter to the soil due to a high plant biomass production (Mishra et al., 2015). Consequently, the structuring of soil is benefited (Calonego et al., 2011), resulting in a favorable pore configuration for the improvement of soil capacity to provide water to plants (Olibone et al., 2010), mitigating high temperature and water deficit effects.

Therefore, the treatments had, in general, not enough time to present more significant differences, due to the NTS formation stage. Reichert et al. (2016) found similar results in soils in the South region of Brazil, but no clear concept for time is found in the literature for soils in the Cerrado biome.

The principal component analysis showed accumulated variance of $81.1 \%$ for the $0-0.05 \mathrm{~m}$ layer, and $82.1 \%$ for the 0.15-0.20 m layer, considering the two principal components: CP1 and CP2 (Table 3). The ordering diagram of the PCA shows that the SOCS was positively correlated with the RAW and PAWC attributes (Figure 1A), mainly for the treatments 3, 4,

A.

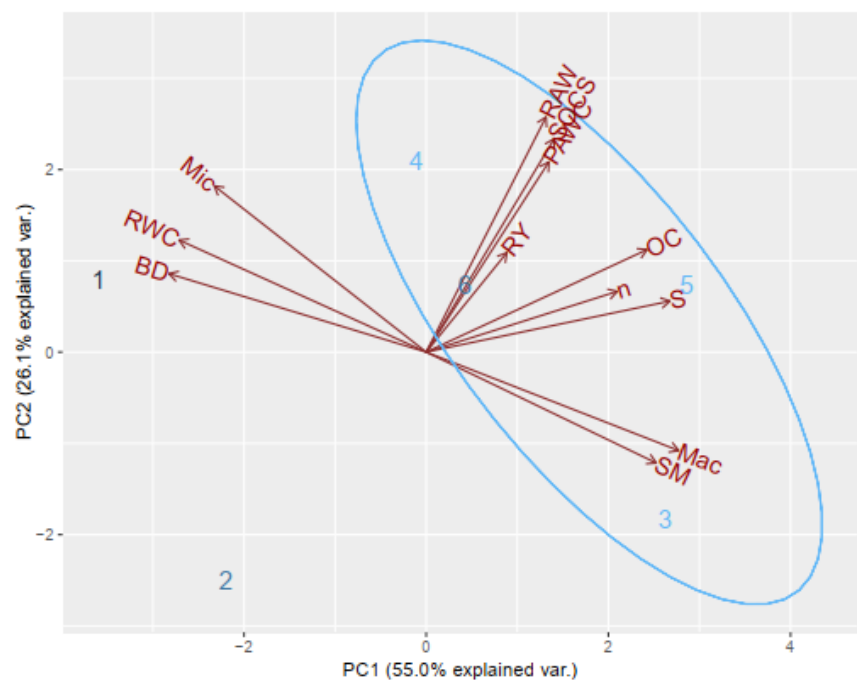

Table 3. First (CP1) and second (CP2) principal components for the evaluated variables in the soil 0-0.05 $\mathrm{m}$ and $0.15-0.20 \mathrm{~m}$ layers of the experiment area

\begin{tabular}{|c|c|c|c|c|}
\hline & CP1 & CP2 & CP1 & CP2 \\
\hline & \multicolumn{2}{|c|}{$0-0.05 \mathrm{~m}$} & \multicolumn{2}{|c|}{$0.15-0.20 \mathrm{~m}$} \\
\hline Eigenvalues & 2.562 & 1.758 & 2.516 & 1.857 \\
\hline Explained variance $(\%)$ & 55 & 26.1 & 52.7 & 29.4 \\
\hline Accumulated explained variance (\%) & 55 & 81.1 & 52.7 & 82.1 \\
\hline Variables & \multicolumn{4}{|c|}{ Eigenvalues } \\
\hline Bulk density & -0.369 & 0.163 & -0.328 & -0.243 \\
\hline Soil microporosity & -0.304 & 0.345 & -0.160 & -0.447 \\
\hline Soil macroporosity & 0.362 & -0.205 & 0.385 & 0.068 \\
\hline Water relative capacity & -0.355 & 0.233 & -0.375 & -0.167 \\
\hline Plant-available water capacity & 0.176 & 0.395 & 0.256 & -0.373 \\
\hline Readily available water & 0.172 & 0.488 & 0.246 & -0.307 \\
\hline Saturation moisture & 0.330 & -0.230 & 0.363 & -0.152 \\
\hline Parameter $\mathrm{n}$ & 0.274 & 0.126 & 0.295 & 0.253 \\
\hline S Index & 0.350 & 0.106 & 0.388 & 0.007 \\
\hline Soil organic carbon & 0.317 & 0.213 & 0.246 & -0.349 \\
\hline Soil organic carbon stocks & 0.184 & 0.443 & 0.053 & -0.493 \\
\hline Relative yield & 0.116 & 0.206 & 0.139 & 0.151 \\
\hline
\end{tabular}

5, and 6, which had crops succession with medium investment, and successions with intercrops with Urochloa ruziziensis with medium and high investments. This result indicates that these treatments had higher increases in soil organic matter, changing the soil structure and improving the soil capacity to provide water to plants. These results are consistent with those of Doran \& Zeiss (2000), who reported correlation between OC and important attributes for soil sustainability, such as water storage and availability.

RY presented positive correlation to RAW, PAWC, SOCS, and OC (Figure 1A), indicating that RY may have been higher due to the high soil capacity to provide water to plants. However, no significant correlation was found between these attributes and RY (Table 4), which can be explained by the short time after the implementation of managements, since the benefits of NTS are better shown after its consolidation (Büchi et al., 2017).

B.

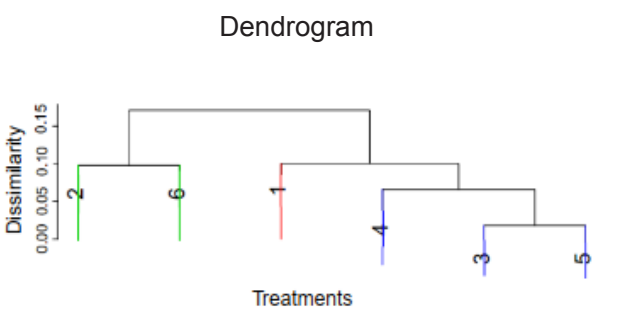

BD - Bulk density; Mic - Soil microporosity; Mac - Soil macroporosity; RWC - Relative water capacity; PAWC - Plant-available water capacity; RAW - Readily available water; SM - Saturation moisture; $\mathrm{n}$ - Fit parameter of the soil water retention curve; S - S Index; OC - Soil organic carbon content; SOCS - Soil organic carbon stocks; RY - Relative yield; 1 - Soybean monoculture; 2 - Maize monoculture; 3 - Soybean-maize succession with medium investment; 4 - Soybean-maize + Urochloa ruziziensis succession with medium investment; 5 - Soybean-maize + Urochloa ruziziensis succession with high investment; 6 - Soybean-maize succession with high investment

Figure 1. Ordering diagram from the principal component analysis for soil variables in the 0-0.05 m layer (A); Dendrogram grouping treatments for the 0-0.05 m layer (B) 
Table 4. Pearson correlation coefficient (r) for soil physical attributes in the 0-0.05 and 0.15 to $0.20 \mathrm{~m}$ layers

\begin{tabular}{|c|c|c|c|c|c|c|c|c|c|c|c|c|}
\hline & RY & SOCS & BD & Mic & Mac & RWC & PAWC & RAW & SM & $n$ & $S$ & OC \\
\hline \multicolumn{13}{|c|}{$0-0.05 \mathrm{~m}$} \\
\hline RY. & 1 & & & & & & & & & & & \\
\hline SOCS & 0.337 & 1 & & & & & & & & & & \\
\hline$B D$ & -0.033 & -0.236 & 1 & & & & & & & & & \\
\hline Mic & -0.116 & 0.136 & $0.887^{*}$ & 1 & & & & & & & & \\
\hline Mac & 0.042 & 0.126 & $-0.991^{*}$ & $-0.924^{*}$ & 1 & & & & & & & \\
\hline RWC & -0.030 & -0.090 & $0.987^{*}$ & $0.941^{*}$ & $-0.999 *$ & 1 & & & & & & \\
\hline PAWC & 0.094 & 0.598 & -0.319 & 0.085 & 0.271 & -0.218 & 1 & & & & & \\
\hline RAW & 0.319 & $0.863^{*}$ & -0.211 & 0.204 & 0.131 & -0.079 & $0.903^{*}$ & 1 & & & & \\
\hline SM & -0.152 & 0.114 & $-0.977^{*}$ & $-0.877^{*}$ & $0.970^{*}$ & $-0.970^{*}$ & 0.257 & 0.095 & 1 & & & \\
\hline$n$ & 0.594 & 0.265 & -0.446 & -0.393 & 0.483 & -0.464 & 0.412 & 0.416 & 0.273 & 1 & & \\
\hline S & 0.475 & 0.371 & -0.718 & -0.583 & 0.733 & -0.710 & 0.554 & 0.512 & 0.574 & $0.931^{*}$ & 1 & \\
\hline $\mathrm{OC}$ & 0.289 & $0.832^{*}$ & -0.730 & -0.424 & 0.649 & -0.624 & 0.553 & 0.698 & 0.625 & 0.452 & 0.671 & 1 \\
\hline \multicolumn{13}{|c|}{$0.15-0.20 \mathrm{~m}$} \\
\hline RY. & 1 & & & & & & & & & & & \\
\hline SOCS & -0.479 & 1 & & & & & & & & & & \\
\hline $\mathrm{BD}$ & -0.377 & 0.267 & 1 & & & & & & & & & \\
\hline Mic & -0.250 & 0.632 & $0.836^{*}$ & 1 & & & & & & & & \\
\hline Mac & 0.336 & -0.023 & $-0.894^{*}$ & -0.581 & 1 & & & & & & & \\
\hline RWC & -0.330 & 0.111 & $0.933^{\star}$ & 0.675 & $-0.993^{*}$ & 1 & & & & & & \\
\hline PAWC & 0.341 & 0.518 & -0.232 & 0.317 & 0.432 & -0.340 & 1 & & & & & \\
\hline RAW & 0.504 & 0.451 & -0.282 & 0.237 & 0.415 & -0.334 & $0.952^{\star}$ & 1 & & & & \\
\hline SM & 0.270 & 0.332 & -0.580 & -0.073 & 0.818 & -0.751 & $0.832^{\star}$ & 0.728 & 1 & & & \\
\hline$n$ & 0.257 & -0.225 & -0.760 & -0.678 & $0.850^{\star}$ & $-0.873^{\star}$ & -0.037 & 0.001 & 0.450 & 1 & & \\
\hline S & 0.351 & 0.065 & $-0.821^{*}$ & -0.468 & $0.987^{\star}$ & $-0.963^{\star}$ & 0.484 & 0.471 & $0.844^{*}$ & $0.850^{*}$ & 1 & \\
\hline $\mathrm{OC}$ & -0.247 & $0.843^{*}$ & -0.288 & 0.159 & 0.478 & -0.412 & 0.618 & 0.596 & 0.631 & 0.235 & 0.532 & 1 \\
\hline
\end{tabular}

* - Significant values by the t test at $\mathrm{p} \leq 0.05$. RY - Relative yield; SOCS - Soil organic carbon stocks; BD - bulk density; Mic - Soil microporosity; Mac - Soil macroporosity RWC - Relative water capacity; PAWC - Plant-available water capacity; RAW - Readily available water; SM - Saturation moisture; $\mathrm{n}$ - Fit parameter of the soil water retention curve; S - S Index; OC - Soil organic carbon content

The attributes microporosity, BD, and RWC presented significant positive correlation to each other, and negative correlation to Mac and SM (Table 4). These correlations are shown by the distribution of vectors of these attributes in the PCA (Figure 1A) and by the correlation of soil porosity to carbon stocks and yield. The treatments that presented higher Mac and SM were those that had the higher SOCS, RAW, PAWC, and RY, indicating a better soil physical quality and favorable conditions to plant growth.

The dendrogram generated by the grouping analysis through similarity levels shows two groups for the $0-0.05 \mathrm{~m}$ layer (Figure 1B). The first group was composed by treatments with maize monoculture with medium investment (2) and soybean-maize succession with high investment (6); and the second group encompassed the treatments with soybean crop monoculture (1), soybean-maize succession with medium investment (3), and soybean-maize + U. ruziziensis succession with medium (4) and high (5) investments. The second group presented a subdivision, differentiating the soybean crop monoculture from the others. The subgroup formed by treatments with soybean-maize succession with medium investment and treatments with soybean-maize $+U$. ruziziensis succession with medium and high investments presented the highest similarity.

The association of these information with the ordering diagram produced by the PCA (Figure 1A) showed a subdivision in the second group represented by the highest values of $\mathrm{BD}$, microporosity, and RWC found in the treatment 1 ; and the treatments 3,4 , and 5 presented the best SPQ and, consequently, the best conditions to plant growth.

The 0.15-0.20 m layer showed the same trend for the SOC vector, correlating with PAWC and RAW, mainly in the treatments 5 and 6, which had intensive crop managements (crop succession with intercrop with U. ruziziensis and crop succession, respectively), both with high level of investment in soil fertilization (Figure 2A). It is expected that soils under intensive crop managements, characterized by association of soil and water conservation practices, such as the NTS or those that include soil cover plants such as $U$. ruziziensis, present significantly higher carbon contents than those under conventional production systems (Plaza et al., 2013; Crusciol et al., 2015).

The analysis of the other physical attributes in the $0.15-0.20 \mathrm{~m}$ layer (Figure 2A) showed positive correlation between Mac, $S$ Index, total porosity, $\mathrm{SM}$, and the parameter $\mathrm{n}$, and negative correlation between BD and RWC. These results show the correlation between $S$ index and parameters related to soil pore dynamics, which were favorable to Mac and inverse to $\mathrm{BD}$ and RWC, as confirmed by the correlation analysis (Table 4).

The BD and RWC vectors were negatively correlated to RY in both soil layers. This indicates a possible soil compaction under these conditions, because the values of physical indicators were below the established limit, indicating degradation of the soil structure (Table 2), which directly impacts the crop relative yield. Compactions found in the treatments 1 and 2 may be resulted from the area use history, with successive crops, which was not solved only with the soil preparation operations. The other treatments, with intensive crop systems (3, 4, 5 and 6) presented different conditions of $\mathrm{BD}$ and RWC.

Considering the trend of increase for the RY vector, RY was negatively correlated to BD and RWC in the layer $0.15-0.20 \mathrm{~m}$, and positively correlated to Mac, $\mathrm{S}$ index and, mainly, to the $\mathrm{n}$ parameter of the van Genuchten equation (Figure 2A). These results indicate that the aeration factor is important to define 
A.

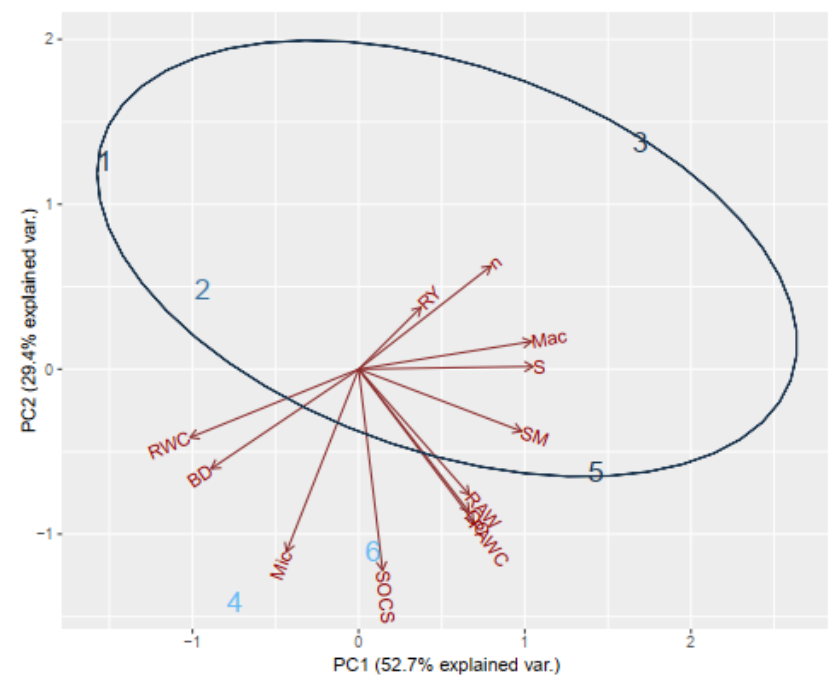

B.

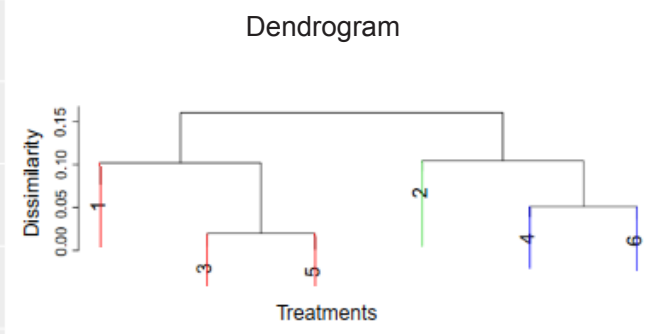

BD - Bulk density; Mic - Soil microporosity; Mac - Soil macroporosity; RWC - Relative water capacity; PAWC - Plant-available water capacity; RAW - Readily available water; SM - Saturation moisture; $\mathrm{n}$ - Fit parameter of the soil water retention curve; S - S Index; OC - Soil organic carbon content; SOCS - Soil organic carbon stocks; RY - Relative yield; 1 - Soybean monoculture; 2 - Maize monoculture; 3 - Soybean-maize succession with medium investment; 4 - Soybean-maize + Urochloa ruziziensis succession with medium investment; 5 - Soybean-maize + Urochloa ruziziensis succession with high investment; 6 - Soybean-maize succession with high investment

Figure 2. Ordering diagram from the principal component analysis for soil variables in the 0.15-0.20 m layer (A); Dendrogram grouping treatments for the 0.15-0.20 m layer (B)

crop yield, but different results were found for the 0-0.05 m layer (Figure 1A). Thus, root growth is favored by the presence of large pores, which promotes better water and nutrient availability in subsurface layers. However, despite the trend of increase for the RY vector (Figure 2A), no significant correlation was found between yield and the attributes studied for the 0.15-0.20 m layer within the evaluated period (Table 4).

The grouping analysis showed the formation of two groups for the 0.15-0.20 m layer (Figure 2B). The first was composed by treatments with soybean monoculture (1), soybean-maize succession with medium investment (3), and soybean-maize $+U$. ruziziensis succession with high investment (5), with a subdivision separating the monoculture from the other treatments. The second group was formed by treatments with maize monoculture (2), soybean-maize succession with high investment (6), and soybean-maize $+U$. ruziziensis succession with medium investment (4), with a subdivision separating the monoculture from the other treatments. The treatment 4 , which presented better SPQ in the 0-0.05 m layer, presented higher $\mathrm{BD}$, microporosity, and RWC in the $0.15-0.20 \mathrm{~m}$ layer, together with the treatments 6 and 2 (Figure 2A), which can limit plant growth. However, the treatment 1 no longer presented limitations regarding $\mathrm{BD}$, presenting improvements in SPQ, grouping it together with the treatments 3 and 5 .

The differences between the treatments 1 and 3 and between the treatments 1 and 5 can be explained by the benefits of the crop successions, which favor the formation of continuous channels throughout the soil profile, favoring root growth and generating a higher carbon accumulation in surface layers (Calonego et al., 2017; Tormena et al., 2017). These benefits can be even greater for intercrops with species that have extensive and vigorous root systems that can pass through denser layers and improve soil structure (Olibone et al., 2010). These systems can also improve the crop tolerance to water deficits and produce expressive quantity of dry matter, which favors soil cover and ensures the sustainability of the NTS (Borghi et al., 2013;
Calonego et al., 2017). Studies have shown that the introduction of perennial grasses species as intercrops for grain productions improves soil chemical fertility (Crusciol et al., 2015) and SPQ in surface and subsurface layers (Calonego et al., 2011) and, consequently, increases maize and soybean crop yields (Crusciol et al., 2015; Balbinot et al., 2017; Pariz et al., 2017).

The treatments 3 and 5 were grouped with high similarity to the others in both soil layers evaluated (Figures $1 \mathrm{~B}$ and 2B). The SPQ indicators related to soil capacity to provide air (Mac) and water (PAWC and RAW) and the pore distribution balance (RWC and S Index) were important for the distinction of these treatments (Figures $1 \mathrm{~A}$ and $2 \mathrm{~A}$ ), indicating which physical factors were improved and tended to improve the SPQ due to the conservationist management. Calonego et al. (2017) found that soil cover crops improved the structure of a very clayey, compacted soil in the medium and long term, presenting similar or higher results to those found for the scarifier, mainly in deep layers, generating higher yields after two years of experiment, confirming the efficiency of using intensive production systems.

Considering the hydrological restrictions of soils in the Cerrado biome, which hinder the adequate establishment of NTS, the results of the present work are important for the technical study of managements that mitigate water stress to plants, mainly for compacted soils. Changes in soil porosity caused by the adoption of continuously soil management and conservationist practices result in formation of continuous pores due to the plant roots and macrofauna activity (biopores), which are preserved by the absence of soil turning, creating important alternative routes for plant root growth (Papadopoulos et al., 2014; Huang et al., 2015; Tormena et al., 2017). This condition contributes to the mitigation of soil compaction, which has been affecting crops yields and the maintenance of environmental services (Mentges et al., 2016), such as the rational use of water, recharge of water tables, and control of erosive processes. 


\section{Conclusions}

1. Intensive management systems show better soil physical quality than soybean and maize monocultures in the short term - after the second summer crop season from their implementation.

2. The most important physical factors for plant growth were the indicators related to a higher water availability to plants in the $0-0.05 \mathrm{~m}$ layer and to a higher soil aeration in the $0.15-0.20 \mathrm{~m}$ layer.

3. Intensive crop managements favor the increase of soil organic carbon stocks, which is correlated to changes in soil porosity, affecting mainly the soil capacity to provide water to plants.

4. Grain yield presented no significant correlation to the evaluated attributes.

\section{ACKNOWLEDGements}

The authors thank the Brazilian National Council for Scientific and Technological Development (CNPq), the Brazilian Coordination for the Improvement of Higher Education Personnel (CAPES), and the Foundation for Research Support of the State of Minas Gerais (FAPEMIG) for the financial support; the Federal University of São João Del-Rei (UFSJ) from granting a study scholarship to the first author; and the professors José Carlos Moraes Rufini and Samuel Petraccone Caixeta and graduation students of the UFSJ for their collaboration.

\section{Literature Cited}

Allen, R. G.; Pereira, L. S.; Raes, D.; Smith. M. Crop evapotranspiration: Guidelines for computing crop water requirements. Rome: Food and Agriculture Organization. 1998. 300p. Drainage and Irrigation Paper. 56

Andrade, R. D. S.; Stone, L. F. Índice S como indicador da qualidade física de solos do cerrado brasileiro. Revista Brasileira de Engenharia Agrícola e Ambiental, v.13, p.382-388, 2009. https:// doi.org/10.1590/S1415-43662009000400003

Balbinot, A. A.; Santos, J. C. F. dos; Debiasi, H.; Yokoyama, A. H. Contribution of roots and shoots of Brachiaria species to soybean performance in succession. Pesquisa Agropecuária Brasileira, v.52, p.592-598, 2017. https://doi.org/10.1590/s0100204x2017000800004

Borghi, E.; Crusciol, C. A. C.; Nascente, A. S.; Sousa. V. V.; Martins, P. O.; Mateus, G. P.; Costa. C. Sorghum grain yield, forage biomass production and revenue as affected by intercropping time. European Journal of Agronomy, v.51, p.130-139, 2013. https:// doi.org/10.1016/j.eja.2013.08.006

Büchi, L.; Wendling, M.; Amossé, C.; Jeangros, B.; Sinaj, S.; Charles, R. Long and short term changes in crop yield and soil properties induced by the reduction of soil tillage in a long term experiment in Switzerland. Soil and Tillage Research, v.174, p.120-129, 2017. https://doi.org/10.1016/j.still.2017.07.002

Calonego, J. C.; Crusciol, C. A. C.; Borghi, E. Intervalo hídrico ótimo e compactação do solo com cultivo consorciado de milho e braquiária. Revista Brasileira de Ciência do Solo, v.35, p.21832190, 2011. https://doi.org/10.1590/S0100-06832011000600033
Calonego, J. C.; Raphael, J. P. A.; Rigon, J. P. G.; Oliveira Neto, L. de; Rosolem, C. A. Soil compaction management and soybean yields with cover crops under no-till and occasional chiseling. European Journal of Agronomy, v.85, p.31-37, 2017. https://doi.org/10.1016/j. eja.2017.02.001

Cecagno, D.; Andrade Costa, S. E. V. G. de; Anghinoni, I.; Kunrath, T. R.; Martins, A. P.; Reichert, J. M.; Gubiani, P. I.; Balerini, F.; Fink, J. R.; Faccio Carvalho, P. C. de. Least limiting water range and soybean yield in a long-term. no-till. integrated crop-livestock system under different grazing intensities. Soil \& Tillage Research, v.156, p.54-62, 2016. https://doi.org/10.1016/j.still.2015.10.005

Crusciol, C. A. C.; Nascente, A. S.; Borghi, E.; Soratto, R. P.; Martins, P. O. Improving soil fertility and crop yield in a tropical region with palisadegrass cover crops. Agronomy Journal, v.107, p.2271-2280, 2015. https://doi.org/10.2134/agronj14.0603

Dexter, A. R. Soil physical quality: Part I - Theory, effects of soil texture, density, and organic matter, and effects on root growth. Geoderma, v.120, p.201-214, 2004. https://doi.org/10.1016/j. geoderma.2003.09.004

Donagemma, G. K.; Campos, D. V. B. de; Calderano, S. B.; Teixeira, W. G.; Viana, J. H. M. Manual de métodos de análise de solo. 2.ed. Rio de Janeiro: Embrapa Solos. Documentos. 132, 2011.

Doran J, W.; Zeiss, M. R. Soil health and sustainability: Managing the biotic component of soil quality. Applied Soil Ecology, v.15, p.3-11. 2000. https://doi.org/10.1016/S0929-1393(00)00067-6

Genuchten, M. T. van. A closed form equation for predicting the hydraulic condictivity of unsaturated soils. Soil Science Society of America Journal, v.44, p.892-898, 1980. https://doi.org/10.2136/ sssaj1980.03615995004400050002x

Huang, M.; Liang, T.; Wang, L.; Zhou, C. Effects of no-tillage systems on soil physical properties and carbon sequestration under long-term wheat-maize double cropping system. Catena, v.128, p.195-202, 2015. https://doi.org/10.1016/j.catena.2015.02.010

Kottek, M.; Grieser, J.; Beck, C.; Rudolf, B.; Rubel, F. World map of the Köppen-Geiger climate classification updated. Meteorologische Zeitschrift, v.15, p.259-263, 2006. https://doi.org/10.1127/09412948/2006/0130

Mentges, M. I.; Reichert, J. M.; Rodrigues, M. F.; Awe, G. O.; Mentges. L. R. Capacity and intensity soil aeration properties affected by granulometry, moisture and structure in no-tillage soils. Geoderma, v.263, p.47-59, 2016. https://doi.org/10.1016/j.geoderma.2015.08.042

Mishra, A. K.; Aggarwal, P.; Bhattacharyya, R.; Das. T. K.; Sharma, A. R.; Singh, R. Least limiting water range for two conservation agriculture cropping systems in India. Soil \& Tillage Research, v.150, p.43-56, 2015. https://doi.org/10.1016/j.still.2015.01.003

Olibone, D.; Encide-Olibone, A. P.; Rosolem, C. A. Least limiting water range and crop yields as affected by crop rotations and tillage. Soil and Use Management, v.26, p.485-493, 2010. https://doi.org/10.1111/ j.1475-2743.2010.00301.x

Papadopoulos, A.; Bird, N. R. A.; Whitmore, A. P.; Mooney, S. J. Does organic management lead to enhanced soil physical quality? Geoderma, v.213, p.435-443, 2014. https://doi.org/10.1016/j. geoderma.2013.08.033

Pariz, C. M.; Costa, C.; Crusciol, C. A. C.; Meirelles, P. R. L.; Castilhos, A. M.; Andreotti, M.; Costa, N. R.; Martello, J. M.; Souza, D. M.; Protes, V. M.; Longhini, V. Z.; Franzluebbers, A. J. Production, nutrient cycling and soil compaction to grazing of grass companion cropping with corn and soybean. Nutrient Cycling in Agroecosystems, v.108, p.35-54, 2017. https://doi.org/10.1007/s10705-016-9821-y 
Plaza, C.; Courtier-Murias, D.; Fernández, J. M.; Polo, A.; Simpson, A. J. Physical chemical, and biochemical mechanisms of soil organic matter stabilization under conservation tillage systems: A central role for microbes and microbial by-products in $\mathrm{C}$ sequestration. Soil Biology and Biochemistry, v.57, p.124-134, 2013. https://doi.org/10.1016/j. soilbio.2012.07.026

R Core Team. R: A language and environment for statistical computing. Vienna: R Foundation for Statistical Computing. 2017. Available on: <https://www.rproject.org/>. Accessed on: Mar. 2018.

Reichert, J. M.; Rosa, V. T. da; Vogelmann, E. S.; Rosa, D. P. da; Horn, R.; Reinert, D. J.; Sattler, A.; Denardin, J. E. Conceptual framework for capacity and intensity physical soil properties affected by short and long-term (14 years) continuous no-tillage and controlled traffic. Soil \& Tillage Research, v.158, p. 123-136, 2016. https://doi.org/10.1016/j. still.2015.11.010

Reichert, J. M.; Suzuki, L. E. A. S.; Reinert, D. J.; Horn, R.; Håkansson, I. Reference bulk density and critical degree-of-compactness for no-till crop production in subtropical highly weathered soils. Soil \& Tillage Research, v.102, p.242-254, 2009. https://doi. org/10.1016/j.still.2008.07.002
Resende, A. V. de; Silva, A. F. da; Borghi, E.; Gontijo Neto, M. M.; Shiratsuchi, L. S.; Pitta, R. M.; Ferreira, A. Tomada de decisão quanto a adubação e manejo de nutrientes por agricultores do Mato Grosso: Dados do Circuito Tecnológico 2015. Sete Lagoas: Embrapa Milho e Sorgo, 30p. Documentos. 203, 2016

Reynolds, W.; Drury, C.; Yang. X.; Tan, C. Optimal soil physical quality inferred through structural regression and parameter interactions. Geoderma, v.146, p.466-474, 2008. https://doi.org/10.1016/j. geoderma.2008.06.017

Silva. B, M.; Oliveira, G. C. de; Serafim, M. E.; Silva, E. A. da; Ferreira, M. M.; Norton, L. D.; Curi, N. Critical soil moisture range for a coffee crop in an oxidic latosol as affected by soil management. Soil \& Tillage Research, v.154, p.103-113, 2015. https://doi. org/10.1016/j.still.2015.06.013

Silva, B. M.; Silva, E. A. da; Oliveira, G. C. de; Ferreira, M. M.; Serafim, M. E. Plant-available soil water capacity: Estimation methods and implications. Revista Brasileira de Ciência do Solo, v.38, p.464475, 2014. https://doi.org/10.1590/S0100-06832014000200011

Souza, D. M. G.; Lobato, E. Cerrado: correção do solo e adubação. 2.ed. Brasília. Embrapa Informação Tecnológica, 2004. 416p.

Tormena, C. A.; Karlen, D. L.; Logsdon, S.; Cherubin, M. R. Corn stover harvest and tillage impacts on near-surface soil physical quality, Soil \& Tillage Research, v.166, p.122-130, 2017. https:// doi.org/10.1016/j.still.2016.09.015 